\title{
Development of a P1 phagemid system for the delivery of DNA into Gram-negative bacteria
}

\author{
Caroline Westwater, David A. Schofield, Michael G. Schmidt, \\ James S. Norris and Joseph W. Dolan \\ Author for correspondence: Caroline Westwater. Tel: +1 8437927703 . Fax: +1 8437922464. \\ e-mail: westwatc@musc.edu
}

Department of Microbiology and Immunology, Medical University of South Carolina, 173 Ashley Avenue BSB-201, Charleston, SC 29403, USA

\begin{abstract}
The inability to transform many clinically important Gram-negative bacteria has hampered genetic studies addressing the mechanism of bacterial pathogenesis. This report describes the development and construction of a delivery system utilizing the broad-host-range transducing bacteriophage P1. The phagemids used in this system contain a P1 pac initiation site to package the vector, a P1 lytic replicon to generate concatemeric DNA, a broad-hostrange origin of replication and an antibiotic-resistance determinant to select bacterial clones containing the recircularized phagemid. Phagemid DNA was successfully introduced by infection and stably maintained in members of the families Enterobacteriaceae (Escherichia coli, Shigella flexneri, Shigella dysenteriae, Klebsiella pneumoniae and Citrobacter freundii) and Pseudomonadaceae (Pseudomonas aeruginosa). In addition to laboratory strains, these virions were used successfully to deliver phagemids to a number of strains isolated from patients. This ability to deliver genetic information to wild-type strains raises the potential for use in antimicrobial therapies and DNA vaccine development.
\end{abstract}

Keywords: delivery system, bacteriophage, gene transfer, transduction

\section{INTRODUCTION}

The ability to deliver genetic information to cells is an essential first step for many powerful investigative approaches. Only a limited number of bacteria (for example, Haemophilus influenzae, Streptococcus pneumoniae and Bacillus subtilis) can be transformed by natural competence (Lorenz \& Wackernagel, 1994). A number of factors however, such as prolonged incubation with calcium chloride, treatment of bacteria with dimethyl sulfoxide, hexaminecobalt and dithiothreitol in the presence of cations, or addition of polyethylene glycol, can induce artificial competence (Hanahan et al., 1991). Genetic information for example can be delivered to Escherichia coli K-12 by transformation of chemically or electro-competent cells, phage transduction and conjugational mating (Benedik, 1989; Dower et al., 1988; Hanahan et al., 1991). However, many bacterial species of clinical, environmental and industrial importance cannot be made competent.

Recombinant DNA manipulations in bacteria typically involve initial cloning and molecular analyses in E. coli, followed by reintroduction of the cloned DNA into the original host genetic background for studies of gene expression and reverse genetics. Some species are recalcitrant to standard transformation techniques. Therefore, genetic analysis of these species is largely impaired. Most bacterial species possess restriction/ modification systems that have evolved to protect the cell from foreign DNA (Bickle \& Krüger, 1993). Modification of DNA can differ between species and among strains of the same species, creating barriers to gene transfer. To facilitate the movement of DNA some transformation protocols are limited to specific strains that are defective in one or more restriction systems (Novick, 1990; Takagi \& Kisumi, 1985). Non-specific barriers such as high intra- or extracellular nuclease activity can also have profound effects on transformation efficiency (Omenn \& Friedman, 1970; Shireen et al., 1990; Wu et al., 2001). Genetic exchange between mutated laboratory strains and clinical or environmental isolates can be hampered by the lack of alternative methods for the delivery of genes.

The ability to electroporate protoplasts, spheroplasts and intact cells has advanced microbiological studies in organisms where other transformation procedures have 
failed (Chassy et al., 1988). However, the generation of cells lacking cell walls can be labour-intensive, timeconsuming and difficult to reproduce. In addition, these methods normally require optimization of numerous strain-dependent parameters for efficient transformation and regeneration. Transformation efficiencies of intact cells can be highly variable depending on the growth media, growth phase and final concentration of cells, composition of the electroporation medium, electric parameters and conditions used to select for transformants.

The bacteriophage P1 has been widely used in the construction of recombinant bacteria because of its ability to transduce chromosomal markers as well as episomes such as $\mathrm{F}$ and R plasmids (Arber, 1960; Lennox, 1955). Besides E. coli B, C and K, P1 can adsorb to and inject its DNA into 25 Gram-negative species (Yarmolinsky \& Sternberg, 1988). Such a lifestyle has resulted in the evolution of an antirestriction function. P1 DNA is only weakly restricted when it infects a cell carrying type I restriction and modification systems even though DNA purified from P1 phage particles is a good substrate for type I restriction enzymes in vitro (Iida et al., 1987). This protection has been attributed to the presence of the defence against restriction proteins, DarA and DarB, within the phage head. The Dar proteins protect any DNA, including transduced DNA, from restriction (Iida et al., 1987).

In this communication, we describe the construction of a phagemid vector, $\mathrm{P} 1 \mathrm{pBHR}-\mathrm{T}$, which can be used for cloning in E. coli or several Gram-negative hosts. We also describe the development of a P1 phage delivery system that will have great use for the movement of P1pBHR-T between a variety of clinically relevant Gram-negative species.

\section{METHODS}

Bacterial strains, plasmids, phage and growth conditions. The bacterial strains, plasmids and phage used in this study are listed in Table 1. Bacterial cells were grown in LuriaBertani medium (LB), LC medium (LB containing $10 \mathrm{mM}$ $\mathrm{MgSO}_{4}$ and $5 \mathrm{mM} \mathrm{CaCl}$ ) or LB agar. Selection for plasmids was accomplished by the addition of kanamycin (Kan, $50 \mu \mathrm{g} \mathrm{ml}^{-1}$ ), ampicillin (Amp, $100 \mu \mathrm{g} \mathrm{ml}^{-1}$ ) or carbenicillin $\left(500 \mu \mathrm{g} \mathrm{ml}^{-1}\right)$ as needed. DNA manipulations were carried out by standard methods (Sambrook et al., 1989).

Construction of P1 phagemid P1pBHR-T. The rationale for the construction of P1pBHR-T is described in Results and the plasmid map is shown in Fig. 1. The elements necessary for P1 packaging, including the pac initiation site and lytic replicon, were inserted initially into the cloning vector pBluescript II SK. The P1 lytic replicon was generated by fusion of two PCRamplified fragments, resulting in a $52 \%$ in-frame deletion of kilA. Primers 5'-ACCGTCCTCGAGACAAGCAATGGAAGCAGGATTTCTTTCACG-3' and 5'-CGTCTCAAGCTTAGCCACTTATTGTTAGGTAGAATTGTCCG-3' (restriction enzyme recognition sites in bold) were used to amplify a 1178 bp PCR fragment, corresponding to the C-terminus of kilA and the entire repL gene. The Xhol/HindIII-digested PCR product was cloned into the corresponding sites of
pBluescript II SK, generating pCW1. The DNA fragment containing the P53 promoter, P53 antisense promoter and Nterminus of kilA was PCR amplified with primers $5^{\prime}$ GTCACACTCGAGCTGGCAGGTTTCTGAGCAGATCG-3' and 5'-GTGGCACTCGAGGAACGAAACTATGCAATTCTGC-3'. The 403 bp XhoI-digested PCR product was cloned into the unique $\mathrm{XhoI}$ site of $\mathrm{pCW} 1$ to yield plasmid $\mathrm{pCW} 2$. The insert was cloned in the same orientation as the repL gene, thereby placing the lytic replicon under the transcriptional control of the $\mathrm{C} 1$ repressor-regulated promoter P53. The P1 packaging site $(p a c)$ was PCR-amplified with primers 5'-GACAGCCTCTAGACAAATAAGCCAGTCAGGAAGCC-3' and 5'-CGTACCGGGATCCAACGTTATCTATCAGGTAATCGCC-3'. The 305 bp XbaI/BamHIdigested PCR product was cloned into the corresponding sites of pCW2. The P1 elements were then PCR-amplified as a cassette (1904 bp) using primers 5'-GTGACACCATGGCTGGCAGGTTTCTGAGCAGATCG-3' and 5'-CGACACCCATGGTCTAGACAAATAAGCCAGTCAGGAAGC-3'. The NcoI-digested PCR product was inserted into the unique NcoI site of the broad-host-range vector pBBR122 (MoBiTec) creating plasmid pCW3. The unique BamHI and $S c a$ I sites of pCW3 were treated with DNA polymerase I Klenow fragment to create blunt ends and transcriptional terminators, $\mathrm{T}_{\mathrm{L} 17}$ (Wright et al., 1992), were then cloned into these sites to generate P1pBHR-T. To facilitate detection of phagemid transduction in $P$. aeruginosa, the ampicillin-resistance gene including its putative promoter was amplified by PCR from pBluescript II SK using primers 5'-CGCTTACAATTTAGGTGGCAC-3' ${ }^{\prime}$ and $5^{\prime}$-AACTTGGTCTGACAGTTACC- ${ }^{\prime}$ ' and cloned into the DraI sites of P1pBHR-T, thereby creating plasmid P1pBHR-bla.

Thermal induction of $\mathrm{P} 1 \mathrm{Cm}$ c1ts 100 lysogens harbouring plasmid P1pBHR-T. The P1 lysogen, C600(P1), was transformed with plasmid P1pBHR-T, and $\mathrm{Kan}^{\mathrm{R}}$ transformants were selected and grown at $32^{\circ} \mathrm{C}$ in LC medium. Overnight cultures were diluted 100 -fold and grown at $32^{\circ} \mathrm{C}$ in $\mathrm{LC}$ medium until the $\mathrm{OD}_{450}$ reached $1 \cdot 0$, at which time the culture was shifted to $42{ }^{\circ} \mathrm{C}$ and aerated in a gyrating water bath until lysis occurred $(1 \mathrm{~h})$. Chloroform $(1 \%, \mathrm{v} / \mathrm{v})$, DNase $\left(10 \mu \mathrm{g} \mathrm{ml}^{-1}\right)$ and RNase $\left(1 \mu \mathrm{g} \mathrm{ml}^{-1}\right)$ were added and incubation was continued for an additional $30 \mathrm{~min}$ at $37^{\circ} \mathrm{C}$. The phage stock was clarified by centrifugation at $2500 \mathrm{~g}$ for $15 \mathrm{~min}$ and passed through a $0 \cdot 2 \mu \mathrm{m}$ filter.

Phagemid delivery and analysis. An overnight culture of the host strain was diluted in LB and grown to mid-exponential phase $\left(\mathrm{OD}_{600} 0 \cdot 4\right)$. The cells were centrifuged at $2500 \mathrm{~g}$ for $10 \mathrm{~min}$ at $4{ }^{\circ} \mathrm{C}$ and concentrated to $\mathrm{OD}_{600} 2 \cdot 0\left(10^{8}\right.$ c.f.u. $\left.\mathrm{ml}^{-1}\right)$ with LC medium. Phage $(100 \mu \mathrm{l})$ was added at various multiplicity of infection (m.o.i.) and allowed to adsorb to the cells $(100 \mu \mathrm{l})$ for $15 \mathrm{~min}$ at $32^{\circ} \mathrm{C}$. LC medium containing $10 \mathrm{mM}$ sodium citrate was added $(800 \mu \mathrm{l})$, and cells were incubated at $32{ }^{\circ} \mathrm{C}$ for $45 \mathrm{~min}$ or $90 \mathrm{~min}$ to allow expression of antibiotic-resistance genes (kanamycin and carbenicillin, respectively). The infected cells were centrifuged at $7000 \mathrm{~g}$ for $5 \mathrm{~min}$ and resuspended in $100 \mu \mathrm{l} \mathrm{LC}$ medium containing $10 \mathrm{mM}$ sodium citrate. Transductants were detected by spotting $7 \cdot 5 \mu \mathrm{l}$ samples of a 10 -fold serial dilution of the mixture onto LB agar plates containing appropriate antibiotic selection. Plates were scored following overnight incubation at $32{ }^{\circ} \mathrm{C}$. No transductants were observed when $10^{7}$ viable bacteria were assayed on selective media in the absence of phage lysate. P1pBHR-T was recovered from transduced cells by the alkaline lysis method (QIAprep miniprep kit, Qiagen). 
Table 1. Characteristics and origins of bacteria, plasmids and phage used in this study

\begin{tabular}{|c|c|c|}
\hline $\begin{array}{l}\text { Bacterium, plasmid } \\
\text { or phage }\end{array}$ & Description or genotype* & $\begin{array}{l}\text { Source or } \\
\text { reference } \dagger\end{array}$ \\
\hline \multicolumn{3}{|l|}{ Bacteria } \\
\hline \multicolumn{3}{|l|}{ E. coli } \\
\hline C600 & thi-1 thr-1 leuB6 lacY1 tonA21 supE44 & Promega \\
\hline $\mathrm{C} 600(\mathrm{P} 1)$ & Cell carries a P1Cm $c 1$ ts.100 prophage & Rosner (1972) \\
\hline JM101 & supE thi $\Delta($ lac-pro $A B)\left[\mathrm{F}^{\prime}\right.$ traD36 proAB lacl $\left.{ }^{\mathrm{a}} \mathrm{Z} \Delta \mathrm{M} 15\right]$ & $\mathrm{NEB}$ \\
\hline JM101(P1) & Cell carries a P1Cm $c 1$ ts.100 prophage & This study \\
\hline $\mathrm{DH} 5 \alpha$ & 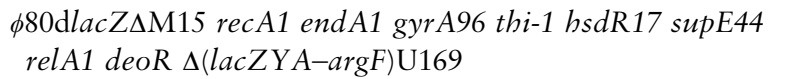 & Gibco-BRL \\
\hline JM109 & $\begin{array}{l}\text { end } A 1 \text { recA1 gyrA96 thi hsdR17 relA1 supE } 44 \Delta(\text { lac-proAB }) \\
{\left[\mathrm{F}^{\prime} \text { traD36 proAB lacl }{ }^{\mathrm{q}} \mathrm{Z} \Delta M 15\right]}\end{array}$ & NEB \\
\hline EC-1 & Urine clinical isolate, $A m p^{R}$ & MUSC \\
\hline EC-2 & Urine clinical isolate, $\mathrm{Amp}^{\mathrm{s}}$ & MUSC \\
\hline \multicolumn{3}{|l|}{$P$. aeruginosa } \\
\hline PAO1 & Clinical isolate & PGSC \\
\hline PA-1 & Clinical isolate & MUSC \\
\hline S. flexneri & Serotype $2 b$ & ATCC 12022 \\
\hline S. dysenteriae & $60 \mathrm{R}$ & J. Butterton $\neq$ \\
\hline C. freundii & Produces restriction endonuclease $C f_{r} \mathrm{~A} 1$ & ATCC 8090 \\
\hline K. pneumoniae & Wild-type & ATCC 10031 \\
\hline $\begin{array}{l}\text { Plasmids } \\
\text { pBluescript II SK } \\
\text { pBBR122 }\end{array}$ & $\begin{array}{l}\text { Cloning vector, ColE1 origin } \\
\text { Cloning vector, broad-host-range origin }\end{array}$ & $\begin{array}{l}\text { Stratagene } \\
\text { MoBiTec }\end{array}$ \\
\hline \multicolumn{3}{|l|}{ Phage } \\
\hline P1Cm $c 1$ ts.100 & Thermoinducible P1Cm & Rosner (1972) \\
\hline
\end{tabular}

*Cm, chloramphenicol marker.

† NEB, New England Biolabs; MUSC, Medical University of South Carolina, Department of Pathology and Laboratory Medicine; PGSC, Pseudomonas Genetic Stock Center, East Carolina University; ATCC, American Type Culture Collection.

‡Dr Joan Butterton, Massachusetts General Hospital, Boston, USA.

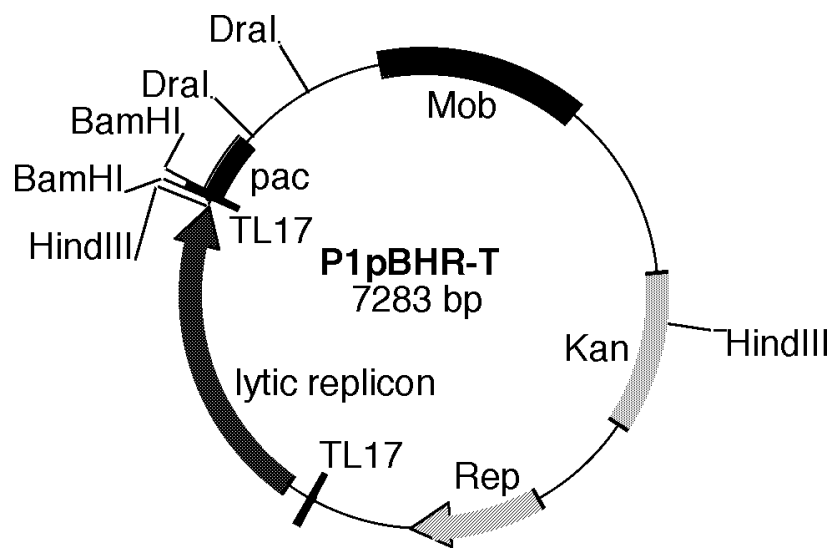

Fig. 1. Map of the broad-host-range phagemid P1pBHR-T. The genes encoding the mobilization protein $(m o b)$, replication protein ( $r e p)$ and kanamycin-resistance marker (kan) are derived from the broad-host-range cloning vector pBBR122. Sequences originating from the P1 bacteriophage include the packaging site (pac) and lytic replicon. The $\mathrm{T}_{\mathrm{L} 17}$ transcriptional terminator is a natural element derived from the $E$. coli $\alpha$ operon (Wright et al., 1992). Only relevant restriction sites are indicated. The sequence of P1pBHR-T is available on request.

\section{RESULTS}

\section{Construction of the $\mathrm{P} 1$ phagemid}

To construct a single vector capable of delivering DNA to a wide range of bacterial species, we constructed a phagemid containing all the essential signals for P1 packaging, a selectable marker for transfer detection, and a broad-host-range origin of replication (P1pBHRT, Fig. 1). The parent plasmid, pBBR122, has been shown to be capable of replicating at medium copy number in at least 26 Gram-negative species and was stably maintained by selective pressure in all Gramnegative organisms tested so far (Antoine \& Locht, 1992; Elzer et al., 1995; Gliesche, 1997; Su et al., 2001). Incompatibility tests have shown that $\mathrm{pBBR} 122$ does not belong to the IncP, IncQ or IncW groups of broad-hostrange plasmids (Antoine \& Locht, 1992). The phagemid P1pBHR-T was also found to be compatible with plasmids containing the ColE1 or p15A origins of replication (data not shown). This is particularly relevant for transfer of the phagemid to clinical and environmental isolates since the majority of such strains may harbour native plasmids. 
(a)
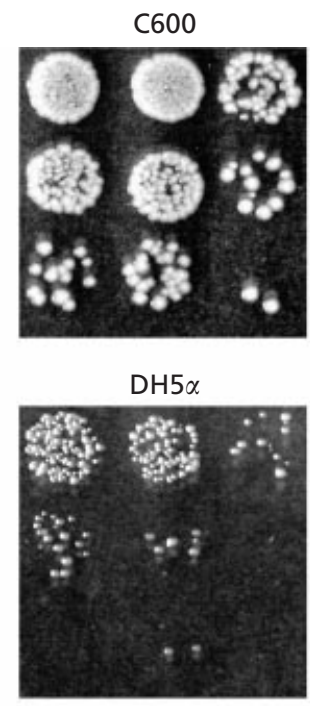

EC-1

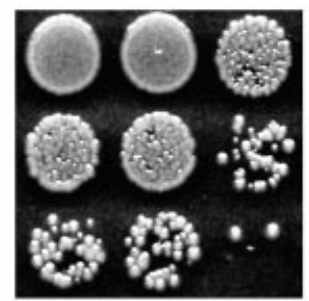

$10^{-2}$

$10^{-3}$

$10^{-4}$
Phage m.o.i.

(b)

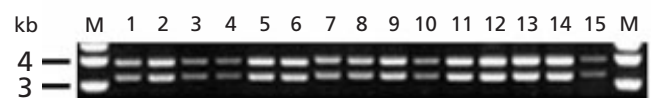

Fig. 2. Transduction of $P 1 p B H R-T$ to $E$. coli isolates. (a) The antibiotic-resistant phenotype conferred by phage infection and delivery of the phagemid is shown in the panels. The ability of bacteriophage P1 to infect and transduce laboratory and clinical isolates of $E$. coli was determined by infecting cells at a m.o.i. of $10^{-2}, 10^{-3}$ or $10^{-4}$. A 10 -fold serial dilution of the infected culture was applied onto media containing $50 \mu \mathrm{g}$ kanamycin $\mathrm{ml}^{-1}$, starting with undiluted (from top to bottom). (b) Restriction digest analysis of E. coli transductants. Plasmid DNA isolated from the parent strain and two representative $\mathrm{Kan}^{\mathrm{R}}$ colonies from each infection were digested with HindIII and analysed by agarose gel electrophoresis. Lane $\mathrm{M}, 1 \mathrm{~kb}$ DNA ladder; lanes 1 and 2, C600; lanes 3 and 4, JM101; lanes 5 and 6 , DH $5 \alpha$; lane 7 , control DNA from parent strain; lanes 8 and 9, JM101 P1 lysogen; lanes 10 and 11, JM109; lanes 12 and 13, EC1; lanes 14 and 15, EC-2. Predicted DNA fragments generated following Hindlll digestion are 3332 and $3951 \mathrm{bp}$. Positions of molecular size standards are indicated on the left.

The elements necessary for packaging into P1 phage capsids were inserted into pBBR122. These elements included the P1 lytic replicon and minimal pac site. The lytic replicon consists of the $\mathrm{C} 1$ repressor-controlled P53 promoter, the promoter P53 antisense and the kilA and repL genes. The KilA protein is not essential for replicon function but is lethal to the bacterial cell. The kilA gene was therefore inactivated by an in-frame deletion, resulting in a protein $52 \%$ of the original size. During the late stages of the phage life cycle the lytic replicon initiates a rolling-circle mode of replication that generates concatemeric DNA, which is the substrate for packaging. Packaging is initiated when phage-encoded proteins recognize and cleave the unique pac site. The DNA is then brought into the empty P1 phage head, and packaging proceeds unidirectionally until the head is full. Since the P1 phage head can package approximately 110-115 kb of DNA (Sternberg, 1990), fragments as large as $100 \mathrm{~kb}$ could potentially be cloned and delivered by this system. The ability to clone high-molecular-mass DNA fragments is important in the analysis of large genes or gene clusters that encode components of biochemical or signalling pathways.

\section{Production of phagemid-containing virions}

The phagemid was maintained in a P1 lysogen which provided all the replication factors needed to activate the lytic cycle and all the structural components to form mature viral particles. The P1 prophage carried a chloramphenicol-resistance marker and the $c 1.100$ temperature-sensitive repressor mutation. This mutation enabled the P1 lytic cycle to be rapidly induced when the temperature of the exponential-phase lysogenic culture was shifted from $32{ }^{\circ} \mathrm{C}$ to $42^{\circ} \mathrm{C}$. Lysates typically contained approximately $80 \% \mathrm{P} 1$ and $20 \%$ phagemid particles as determined by infecting E. coli C600 and $\mathrm{C} 600(\mathrm{P} 1)$, respectively (data not shown).

\section{Delivery to multiple strains of $E$. coli}

The ability to deliver the phagemid to multiple strains of bacteria was tested first with laboratory strains and clinical isolates of $E$. coli. Since the host recombination system may affect concatemer resolution and plasmid rearrangement, $\mathrm{RecA}^{+}$(C600 and JM101) and RecA (DH5 $\alpha$ and JM109) strains were included. Increasing titres of phage were added to fixed numbers of bacterial cells and limited to a single round of infection by the addition of $10 \mathrm{mM}$ sodium citrate. After infection, phagemid-containing transductants were selected by virtue of their ability to grow in the presence of antibiotics. As shown in Fig. 2(a), the total number of transductants increased progressively as the m.o.i. increased. Antibiotic-resistant colonies were not recovered if the phage lysate or cells were tested alone. Since the P1 prophage carried the $c 1.100$ mutation, cells infected with this phage were rendered temperature sensitive. Therefore, to minimize induction of the P1 lytic cycle and maximize the number of transductants recovered all procedures were performed at $32^{\circ} \mathrm{C}$.

Following injection into the bacterial host, P1 DNA must be recircularized before it is rapidly degraded by cellular nucleases. The Cre-loxP site-specific recombination system plays an important role in the cyclization of P1 DNA (Hochman et al., 1983; Segev \& Cohen, 1981; Sternberg et al., 1986). Only two components are 
(a)

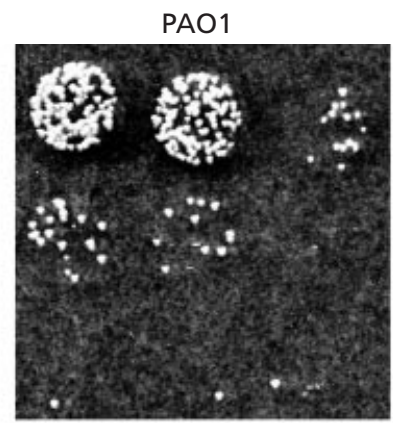

PA-1

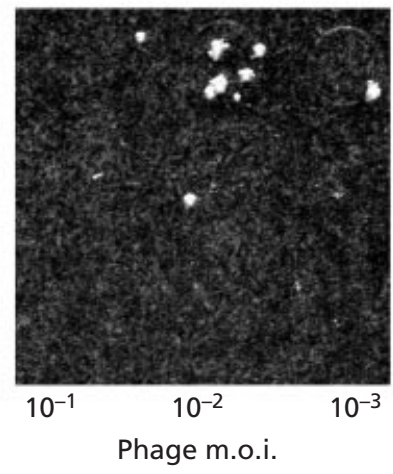

(b)

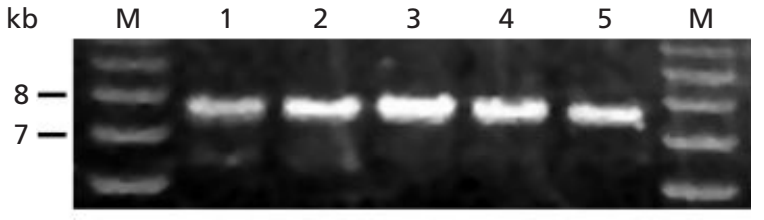

Fig. 3. Transduction of $\mathrm{P} 1 \mathrm{pBHR}$-bla to $P$. aeruginosa. (a) The ability of bacteriophage P1 to infect and transduce laboratory and clinical isolates of $P$. aeruginosa was determined by infecting cells at a m.o.i. of $10^{-1}, 10^{-2}$ or $10^{-3}$. A 10 -fold serial dilution of the infected culture was applied onto media containing carbenicillin at $500 \mu \mathrm{g} \mathrm{ml}^{-1}$, starting with undiluted (from top to bottom). Successful delivery and replication of the phagemid can be visualized by acquisition of the antibiotic marker bla. (b) Restriction digest analysis of $P$. aeruginosa transductants. Plasmid DNA isolated from the parent strain and two representative carbenicillin-resistant colonies from each infection was digested with $\mathrm{BamHI}$ and analysed by agarose gel electrophoresis. Lane M, 1 kb DNA ladder; lanes 1 and 2, PAO1; lane 3, control DNA from parent strain; lanes 4 and 5, PA-1. Predicted DNA fragments generated following BamHI digestion are 7920 and $42 \mathrm{bp}$. Positions of molecular size markers are indicated on the left.

required for this system: a loxP site on the P1 DNA and a P1-encoded recombinase protein, Cre (Sternberg \& Hamilton, 1981). The phagemid must, however, utilize an alternative mechanism for cyclizing its DNA since it does not contain a cre-loxP region. It is assumed that the transduced plasmid multimers are resolved in the recipient to single copies of the plasmid or possibly circular multimers. Consequently, the number of recovered transductants is a function of not only the m.o.i. but also the efficiency of recircularization. (a)

K. pneumoniae

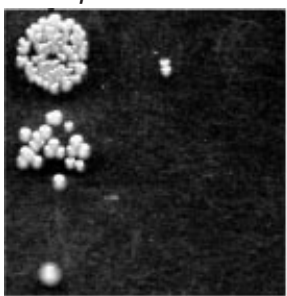

(b)

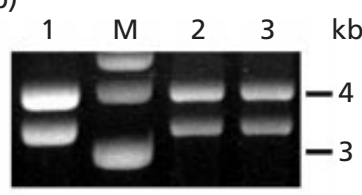

C. freundii
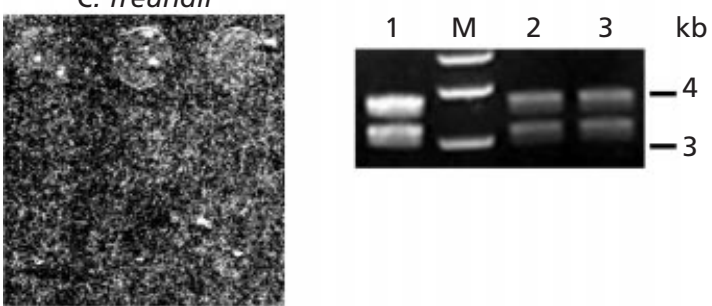

S. flexneri

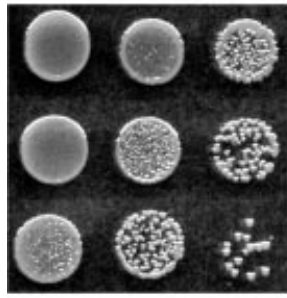

(c)

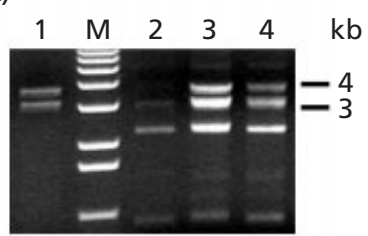

S. dysenteriae
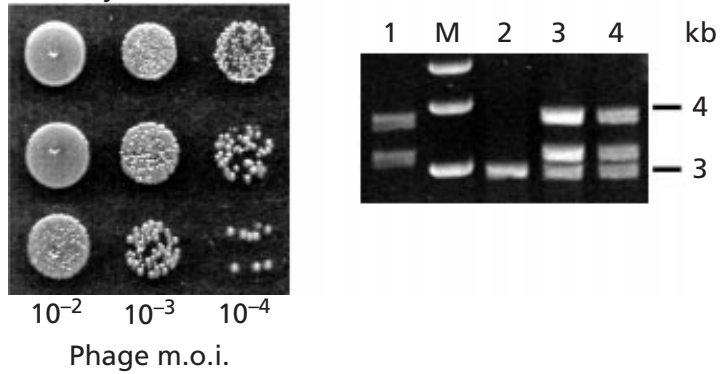

Fig. 4. Transduction of $\mathrm{P} 1 \mathrm{pBHR}-\mathrm{T}$ to $K$. pneumoniae, $C$. freundii, S. flexneri and $S$. dysenteriae. (a) Bacterial species were infected by $\mathrm{P} 1$ at a m.o.i. of $10^{-2}, 10^{-3}$ and $10^{-4}$ and $10-$ fold serial dilutions of phage-infected cultures were applied onto media containing kanamycin at $50 \mu \mathrm{g} \mathrm{ml}^{-1}$, starting with undiluted (from top to bottom). Presumptive transductants harbouring the phagemid P1pBHR-T were selected by virtue of their resistance to kanamycin. (b) Restriction digest analysis of $K$. pneumoniae and $C$. freundii transductants. Plasmid DNA isolated from the parent strain and two representative $\mathrm{Kan}^{R}$ colonies from each infection were digested with HindIII and analysed by agarose gel electrophoresis. Lane $M, 1 \mathrm{~kb}$ DNA ladder; lane 1, control DNA from parent strain; lanes 2 and 3, DNA isolated from $\mathrm{Kan}^{\mathrm{R}}$ transductants. Predicted DNA fragments generated following Hindlll digestion are 3332 and $3951 \mathrm{bp}$. Positions of molecular size standards are indicated on the right. (c) Restriction digest analysis of $S$. flexneri and $S$. dysenteriae transductants. Control DNA or plasmid DNA isolated from $\mathrm{Kan}^{\mathrm{R}}$ colonies was digested with HindIII and analysed by agarose gel electrophoresis. Lane $M, 1 \mathrm{~kb}$ ladder; lane 1, control DNA isolated from parent strain; lane 2, $S$. flexneri and $S$. dysenteriae strains harbouring an endogenous plasmid; lanes 3 and 4, transductants. Predicted DNA fragments generated following HindIII digestion are 3332 and 3951 bp. Positions of molecular size markers are indicated on the right. 
Successful delivery of P1pBHR-T was confirmed by extraction of this plasmid from representative isolates. Antibiotic-resistant transductants harboured plasmid DNA whose migration was identical to that originally seen in the parent strain (Fig. 2b). Restriction enzyme digestion demonstrated that gross deletions or genetic rearrangements in P1pBHR-T did not occur as a consequence of packaging or recircularization. Acquisition of $\mathrm{P} 1 \mathrm{pBHR}-\mathrm{T}$ did not result in displacement (incompatibility) of native plasmids in clinical isolates (data not shown).

\section{The delivery vehicle can transduce many Gram- negative species}

To demonstrate the utility of the delivery system, transduction of the phagemid was tested in various Gram-negative bacteria including Pseudomonas aeruginosa, Klebsiella pneumoniae, Citrobacter freundii, Shigella flexneri and Shigella dysenteriae. All the bacteria tested were successfully transduced by the P1 delivery system (Figs $3 \mathrm{a}$ and $4 \mathrm{a}$ ). The $P$. aeruginosa clinical isolate PA-1 was transduced at a lower efficiency than the laboratory strain PAO1 (Fig. 3a). It is noteworthy that a similar effect has been reported for electroporation of $P$. aeruginosa isolates from lung sputum of cystic fibrosis patients and wild-type strains isolated from different sources for other Gram-negative species (Diver et al., 1990; Wirth et al., 1989). Functionality of the pBBR122 origin of replication among the Gram-negative species was confirmed by extraction and analysis of P1pBHR-T from representative transductants (Figs $3 \mathrm{~b}, 4 \mathrm{~b}$ and $4 \mathrm{c}$ ).

The majority of bacteria carry plasmids or lysogenized phage that protect their host by expressing potent activities that prevent infection by other phages (for reviews, see Dinsmore \& Klaenhammer, 1995; Snyder, 1995). This is particularly relevant for transduction of environmental $P$. aeruginosa strains since $40 \%$ of isolates recovered from natural ecosystems (lake water, sediment, soil and sewage) contain DNA sequences homologous to phage genomes (Ogunseitan et al., 1992). The P1 delivery system, however, does not appear to be under the constraints of superinfection exclusion since P1pBHR-T can be successfully delivered to a P1 lysogen (data not shown). The phagemid was also introduced by infection into S. flexneri and S. dysenteriae strains harbouring a natural resident plasmid (Fig. 4c).

\section{DISCUSSION}

In this study, phagemid DNA was readily introduced into a variety of Gram-negative bacteria, including $E$. coli, via a P1 phage delivery system. Phagemid P1pBHR$\mathrm{T}$ is a relatively small plasmid $(7 \cdot 3 \mathrm{~kb})$ containing one or two antibiotic-resistance determinants $\left(\mathrm{Kan}^{\mathrm{R}}\right.$ and/or $\left.A m p^{R}\right)$. Both are readily selectable markers for Gramnegative bacteria. The ability to screen presumptive transductants for antibiotic resistance was a reliable and simple means of phenotypically confirming transduction of the phagemid to E. coli and other Gram-negative bacteria. The functionality of the pBBR122 origin of replication among Gram-negative bacteria was also extended further in this study.

Since the various Gram-negative bacteria accepted DNA packaged from another bacterial genus (E. coli), this suggested protection of the DNA by the P1 Dar proteins. Both the DarA and DarB proteins were provided by the P1 prophage and are thought to be incorporated into the phagemid-carrying P1 capsids during lysate production. These internal head proteins have been shown to bind phage DNA and are injected along with the infecting DNA into the recipient cell. Moreover, DNA binding is not specific for the P1 phage genome because any DNA packaged into a P1 phage head has been shown to be protected against restriction (Iida et al., 1987). Alternatively, the species tested may simply not possess an effective restriction/modification system or the transduced phagemid DNA may lack a restriction endonuclease recognition sequence recognized by these systems. The results obtained suggest that the delivery system may be applicable to the transduction of many different Gram-negative bacteria. There are additional bacterial species to which it should be possible to extend this P1 delivery system. The host range of P1 includes, for example, Yersina pestis, Yersina pseudotuberculosis and Salmonella typhimurium (Lawton \& Molnar, 1972; Murooka \& Harada, 1979; Okada \& Watanabe, 1968).

This procedure could be used for many genetic approaches, including the construction of strains, heterologous expression of genes and proteins, and analysis of endogenous gene expression. One important advantage of a phage delivery system is that, in contrast to transformation, phage infection normally occurs at high frequency in hosts competent for that phage. Low transformation efficiency of many bacteria has prevented the introduction of a gene library into these bacteria for direct complementation. In addition to using this procedure for the generation of recombinant bacteria, it should also be possible to construct genomic libraries in the phagemid vector. After obtaining transformants in E. coli the library could be pooled and infected en masse with P1 phage, generating an entire packaged library. This could be used to transduce any P1-sensitive host in vitro and in vivo. Bacterial transduction has been reported in environmental settings such as marine and freshwater aquatic habitats and in soil (Miller, 1998; Zeph et al., 1988). In this regard, the P1 delivery system could be helpful in addressing questions concerning the fate of genetically engineered vectors released into these environments and the transfer by transduction of DNA to indigenous organisms.

One of the challenges of current molecular therapy is how to deliver the therapeutic agent to the offending bacterium. Because of their importance as pathogens, effort was directed towards the development of delivery vectors and improvements of methods to introduce recombinant DNA molecules into Gram-negative bac- 
teria that are not naturally competent. Clinically important micro-organisms that are rapidly developing resistance to available antimicrobials include Gramnegative bacteria that cause urinary tract infections (Gupta et al., 1999), foodborne infections (Glynn et al., 1998), bloodstream infections (Pittet \& Wenzel, 1995) and infections transmitted in health-care settings (Richard et al., 1994; Wiener et al., 1999). Besides being a valuable tool for delivering DNA in vitro this technology provides the opportunity for targeting bacterial cells in vivo. This system could be used as a delivery vehicle for oral vaccines if the natural enteric flora of the gastrointestinal tract was targeted. In this approach P1 phage would deliver phagemids engineered to express pathogen-specific immunogenic epitopes on the surface of the bacteria (Zuercher et al., 2000). Alternatively, phage-delivered vectors could direct oral bacteria to secrete salivary histatin or other antimicrobial peptides (Hancock \& Chapple, 1999). This approach may be useful in the management of mucosal candidiasis and development of antimicrobial therapies.

\section{ACKNOWLEDGEMENTS}

We are grateful to Dr M. Yarmolinsky for providing the thermoinducible phage P1Cm. We would also like to thank Dr L. Steed and $\operatorname{Dr}$ J. Butterton for providing clinical isolates. DNA sequencing data were obtained by the Biotechnology Resource Laboratory of the Medical University of South Carolina. This work was supported by Hexal AG, Holzkirchen, Germany.

\section{REFERENCES}

Antoine, R. \& Locht, C. (1992). Isolation and molecular characterization of a novel broad-host-range plasmid from Bordetella bronchiseptica with sequence similarities to plasmids from Grampositive organisms. Mol Microbiol 6, 1785-1799.

Arber, W. (1960). Transduction of chromosomal genes and episomes in Escherichia coli. Virology 11, 273-288.

Benedik, M. J. (1989). High efficiency transduction of single strand plasmid DNA into enteric bacteria. Mol Gen Genet 218, 353-354.

Bickle, T. A. \& Krüger, D. H. (1993). Biology of DNA restriction. Microbiol Rev 57, 434-450.

Chassy, B. M., Mercenier, A. \& Flickinger, J. (1988). Transformation of bacteria by electroporation. Tibtech 6, 303-309.

Dinsmore, P. K. \& Klaenhammer, T. R. (1995). Bacteriophage resistance in Lactococcus. Mol Biotechnol 4, 297-314.

Diver, J. M., Bryan, L. E. \& Sokol, P. A. (1990). Transformation of Pseudomonas aeruginosa by electroporation. Anal Biochem 189, 75-79.

Dower, W. J., Miller, J. F. \& Ragsdale, C. W. (1988). High efficiency transformation of E. coli by high voltage electroporation. Nucleic Acids Res 16, 6127-6145.

Elzer, P. H., Kovach, M. E., Phillips, R. W., Robertson, G. T., Peterson, K. M. \& Roop, M. R. (1995). In vivo and in vitro stability of the broad-host-range cloning vector pBBR1MCS in six Brucella species. Plasmid 33, 51-57.

Gliesche, C. G. (1997). Transformation of methylotrophic bacteria by electroporation. Can J Microbiol 43, 197-201.
Glynn, M. K., Bopp, C., Dewitt, W., Dabney, P., Mokhtar, M. \& Angulo, F. L. (1998). Emergence of multidrug-resistant Salmonella enterica serotype typhimurium DT104 infections in the United States. N Engl J Med 338, 1333-1338.

Gupta, K., Scholes, D. \& Stamm, W. E. (1999). Increasing prevalence of antimicrobial resistance among uropathogens causing acute uncomplicated cystitis in women. JAMA ( $\mathrm{J} \mathrm{Am}$ Med Assoc) 281, 736-738.

Hanahan, D., Jessee, J. \& Bloom, F. R. (1991). Plasmid transformation of Escherichia coli and other bacteria. Methods Enzymol 204, 63-113.

Hancock, R. E. W. \& Chapple, D. S. (1999). Peptide antibiotics. Antimicrob Agents Chemother 43, 1317-1323.

Hochman, L., Segev, N., Sternberg, N. \& Cohen, G. (1983). Sitespecific recombinational circularization of bacteriophage P1 DNA. Virology 131, 11-17.

lida, S., Streiff, M. B., Bickle, T. A. \& Arber, W. (1987). Two DNA antirestriction systems of bacteriophage $\mathrm{P} 1, \operatorname{dar} A$, and $\operatorname{dar} B$ : characterization of dar $A^{-}$phages. Virology 157, 156-166.

Lawton, W. D. \& Molnar, D. M. (1972). Lysogenic conversion of Pasteurella by Escherichia coli bacteriophage P1 Cm. J Virol 9, 708-709.

Lennox, E. S. (1955). Transduction of linked genetic characters of the host by bacteriophage P1. Virology 1, 190-206.

Lorenz, M. G. \& Wackernagel, W. (1994). Bacterial gene transfer by natural genetic transformation in the environment. Microbiol Rev 58, 563-602.

Miller, R. V. (1998). Bacterial gene swapping in nature. Sci Am 47, 67-71.

Murooka, Y. \& Harada, T. (1979). Expansion of the host range of coliphage P1 and gene transfer from enteric bacteria to other Gram-negative bacteria. Appl Environ Microbiol 30, 754-757.

Novick, R. P. (1990). The staphylococcus as a molecular genetic system. In Molecular Biology of the Staphylococci, pp. 1-37. Edited by R. P. Novick. New York: VCH Publishers.

Ogunseitan, O. A., Sayler, G. S. \& Miller, R. V. (1992). Application of DNA probes to analysis of bacteriophage distribution patterns in the environment. Appl Environ Microbiol 58, 2046-2052.

Okada, M. \& Watanabe, T. (1968). Transduction with phage P1 in Salmonella typhimurium. Nature 218, 185-187.

Omenn, G. S. \& Friedman, J. (1970). Isolation of mutants of Staphylococcus aureus lacking extracellular nuclease activity. J Bacteriol 101, 921-924.

Pittet, D. \& Wenzel, R. P. (1995). Nosocomial bloodstream infections. Secular trends in rates, mortality, and contribution to total hospital deaths. Arch Intern Med 155, 1177-1184.

Richard, P., Le Floch, R., Chamoux, C., Pannier, M., Espaze, E. \& Richet, H. (1994). Pseudomonas aeruginosa outbreak in a burn unit: role of antimicrobials in the emergence of multiply resistant strains. J Infect Dis 170, 377-383.

Rosner, J. L. (1972). Formation, induction, and curing of bacteriophage P1 lysogens. Virology 49, 679-689.

Sambrook, J., Fritsch, E. F. \& Maniatis, T. (1989). Molecular Cloning: a Laboratory Manual, 2nd edn. Cold Spring Harbor, NY: Cold Spring Harbor Laboratory.

Segev, N. \& Cohen, G. (1981). Control of circularization of bacteriophage P1 DNA in Escherichia coli. Virology 114, 333-342.

Shireen, T., Sarker, M. R. \& Ahmed, Z. U. (1990). Studies on transformation in Shigella. Can J Microbiol 36, 348-351. 
Snyder, L. (1995). Phage-exclusion enzymes: a bonanza of biochemical and cell biology reagents? Mol Microbiol 15, 415-420.

Sternberg, N. (1990). Bacteriophage P1 cloning system for the isolation, amplification, and recovery of DNA fragments as large as 100 kilobase pairs. Proc Natl Acad Sci US A 87, 103-107.

Sternberg, N. \& Hamilton, D. (1981). Bacteriophage P1 sitespecific recombination. J Mol Biol 150, 467-486.

Sternberg, N., Sauer, B., Hoess, R. \& Abremski, K. (1986). Bacteriophage P1 cre gene and its regulatory region. Evidence for multiple promoters and for regulation by DNA methylation. $J$ Mol Biol 187, 197-212.

Su, H., Shao, Z., Tkalec, L., Blain, F. \& Zimmerman, J. (2001). Development of a genetic system for the transfer of DNA into Flavobacterium heparinum. Microbiology 147, 581-589.

Takagi, T. \& Kisumi, M. (1985). Isolation of a versatile Serratia marcescens mutant as a host and molecular cloning of the aspartase gene. J Bacteriol 161, 1-6.

Wiener, J., Quinn, J. P., Bradford, P. A., Goering, R. V., Nathan, C., Bush, K. \& Weinstein, R. A. (1999). Multiple antibiotic-resistant Klebsiella and Escherichia coli in nursing homes. JAMA ( $\mathrm{Am}$ Med Assoc) 281, 517-523.

Wirth, R., Friesenegger, A. \& Fiedler, S. (1989). Transformation of various species of Gram-negative bacteria belonging to 11 different genera by electroporation. Mol Gen Genet 216, 175-177.

Wright, J. J., Kumar, A. \& Hayward, R. S. (1992). Hypersymmetry in a transcriptional terminator of Escherichia coli confers increased efficiency as well as bidirectionality. EMBO J 11, 1957-1964.

Wu, S., Lo, S., Shao, C., Tsai, H. \& Hor, L. (2001). Cloning and characterization of a periplasmic nuclease of Vibrio vulnificus and its role in preventing uptake of foreign DNA. Appl Environ Microbiol 67, 82-88.

Yarmolinsky, M. B. \& Sternberg, N. (1988). Bacteriophage P1. In The Bacteriophages, vol. 1, pp. 291-438. Edited by R. Calendar. New York: Plenum.

Zeph, L. R., Onaga, M. A. \& Stotzky, G. (1988). Transduction of Escherichia coli by bacteriophage P1 in soil. Appl Environ Microbiol 54, 1731-1737.

Zuercher, A. W., Miescher, S. M., Vogel, M., Rudolf, M. P., Stadler, M. B. \& Stadler, B. M. (2000). Oral anti-IgE immunization with epitope-displaying phage. Eur J Immunol 30, 128-135.

Received 7 August 2001; revised 16 November 2001; accepted 21 November 2001 